\title{
The role of 2 FOXP3 isoforms in the generation of human CD4+ Tregs
}

\author{
Sarah E. Allan, ${ }^{1}$ Laura Passerini, ${ }^{2}$ Rosa Bacchetta, ${ }^{2}$ Natasha Crellin, ${ }^{1}$ Minyue Dai, ${ }^{1}$ Paul C. Orban, ${ }^{2}$ \\ Steven F. Ziegler, ${ }^{3}$ Maria Grazia Roncarolo, ${ }^{2,4}$ and Megan K. Levings ${ }^{1}$
}

${ }^{1}$ Department of Surgery, University of British Columbia, and Immunity and Infection Research Centre, Vancouver Coastal Health Research Institute, Vancouver, British Columbia, Canada. ${ }^{2}$ San Raffaele Telethon Institute for Gene Therapy (HSR-TIGET), San Raffaele Scientific Institute, Milan, Italy. ${ }^{3}$ mmmunology Program, Benaroya Research Institute at Virginia Mason, Seattle, Washington, USA. ${ }^{4}$ Università Vita-Salute San Raffaele, Milan, Italy.

\begin{abstract}
Little is known about the molecules that control the development and function of CD4 ${ }^{+} \mathrm{CD} 25^{+}$Tregs. Recently, it was shown that the transcription factor FOXP3 is necessary and sufficient for the generation of $\mathrm{CD}^{+} \mathrm{CD}^{2} 5^{+}$ Tregs in mice. We investigated the capacity of FOXP3 to drive the generation of suppressive $\mathrm{CD}^{+} \mathrm{CD}^{2} 5^{+} \mathrm{Tregs}$ in humans. Surprisingly, although ectopic expression of FOXP3 in human CD4 ${ }^{+} \mathrm{T}_{\text {cells resulted in induction }}$ of hyporesponsiveness and suppression of IL-2 production, it did not lead to acquisition of significant suppressor activity in vitro. Similarly, ectopic expression of FOXP3 $\Delta 2$, an isoform found in human $\mathrm{CD}^{+} \mathrm{CD}^{2} 5^{+}$ Tregs that lacks exon 2, also failed to induce the development of suppressor T cells. Moreover, when FOXP3 and FOXP3 $\triangle 2$ were simultaneously overexpressed, although the expression of several Treg-associated cell surface markers was significantly increased, only a modest suppressive activity was induced. These data indicate that in humans, overexpression of FOXP3 alone or together with FOXP3 $\Delta 2$ is not an effective method to generate potent suppressor $\mathrm{T}$ cells in vitro and suggest that factors in addition to FOXP3 are required during the process of activation and/or differentiation for the development of bona fide Tregs.
\end{abstract}

\section{Introduction}

Immunological homeostasis is maintained by specialized subsets of $\mathrm{T}$ cells known as Tregs. Evidence points to the existence of 2 types of $\mathrm{CD} 4^{+}$Tregs, those induced by antigen in the periphery (i.e., Treg1 and $\mathrm{Th} 3$ cells) and those that arise in the thymus (i.e., $\mathrm{CD} 4^{+} \mathrm{CD} 25^{+}$ Tregs) (1-3). Antigen-induced CD4+ Tregs typically regulate immune homeostasis via production of cytokines, whereas $\mathrm{CD} 4^{+} \mathrm{CD} 25^{+}$Tregs operate via a cytokine-independent mechanism.

$\mathrm{CD} 4^{+} \mathrm{CD} 25^{+}$Tregs isolated from human peripheral blood are hyporesponsive and strongly suppress the proliferation of, and cytokine production from, both naive and memory $\mathrm{T}$ cells in vitro (4-8). Their suppressive activity is related to their ability to inhibit IL-2 production and promote cell-cycle arrest in both $\mathrm{CD} 4^{+}$and $\mathrm{CD}^{+} \mathrm{T}$ cells, via a mechanism that requires direct cell-to-cell contact and remains to be elucidated. Despite their low proliferative capacity, $\mathrm{CD} 4^{+} \mathrm{CD} 25^{+}$Tregs can be expanded in vitro and retain their potent suppressive effects $(4,9,10)$. $\mathrm{CD}^{+} \mathrm{CD} 25^{+}$Tregs constitutively express high levels of CD25, CTLA4, and glucocorticoid-induced TNF receptor (GITR) and a number of other activation markers $(4-8,11,12)$.

Several groups have suggested that there may be a correlation between $\mathrm{CD} 4{ }^{+} \mathrm{CD} 25^{+}$Tregs and a fatal X-linked autoimmune disorder known as scurfy in mice and immune dysregulation, polyendocrinopathy, enteropathy, X-linked syndrome (IPEX) in humans (13-16). Analysis of the transcription factor FOXP3, which is mutated in these diseases, demonstrated that murine $\mathrm{CD} 4^{+} \mathrm{CD} 25^{+}$ Tregs express high levels of Foxp3 mRNA. Importantly, Foxp3 is not

Nonstandard abbreviations used: GITR, glucocorticoid-induced TNF receptor; hFOXP3, human FOXP3; IPEX, immune dysregulation, polyendocrinopathy, enteropathy, X-linked syndrome; MFI, mean fluorescence intensity; NFAT, nuclear factor of activated T cells; NGFR, nerve growth factor receptor.

Conflict of interest: The authors have declared that no conflict of interest exists.

Citation for this article: J. Clin. Invest. 115:3276-3284 (2005).

doi:10.1172/JCI24685. induced upon activation of nonsuppressive murine $\mathrm{CD} 4^{+} \mathrm{CD} 25^{-} \mathrm{T}$ cells (14-16). Thus, Foxp3 represents the first truly specific marker for murine $\mathrm{CD}^{+} \mathrm{CD} 25^{+}$Tregs. Moreover, analysis of genetically deficient mice shows that Foxp3 appears to be necessary for the generation of suppressive $\mathrm{CD} 4^{+} \mathrm{CD} 25^{+}$Tregs (16). Remarkably, murine $\mathrm{CD} 4^{+} \mathrm{T}$ cells that overexpress Foxp3 following retrovirusmediated gene transfer acquire both the phenotypic and functional characteristics of $\mathrm{CD}^{+}{ }^{+} \mathrm{CD} 25^{+}$Tregs (14-16).

The urgent need for homogenous and antigen-specific populations of human $\mathrm{CD} 4^{+} \mathrm{CD} 25^{+}$Tregs for further biological study, and possibly also clinical applications, prompted us to investigate whether ectopic expression of FOXP3 in human $\mathrm{CD} 4^{+} \mathrm{T}$ cells acts as a molecular switch to induce Tregs in vitro.

\section{Results}

Expression of FOXP3 in buman $\mathrm{CD} 4^{+} T$ cell subsets. Recent studies indicating that in the mouse, expression of Foxp3 is restricted to the suppressive $\mathrm{CD} 4^{+} \mathrm{CD} 25^{+}$Treg subset $(15,16)$ led us to investigate whether this was also true in human $\mathrm{CD} 4^{+} \mathrm{CD} 25^{+}$Tregs. As expected, resting human $\mathrm{CD} 4^{+} \mathrm{CD} 25^{+}$Tregs express significantly higher levels of both FOXP3 mRNA and protein than do $\mathrm{CD} 4^{+} \mathrm{CD} 25^{-}$ T cells (Figure 1A) $(17,18)$.

We also investigated whether expression of FOXP3 could be induced following activation of nonregulatory $\mathrm{CD}^{+} \mathrm{T}$ cells. $\mathrm{CD} 4^{+} \mathrm{CD} 25^{-} \mathrm{T}$ cells, which had been highly purified to ensure that no $\mathrm{CD} 25^{+}$cells contaminated the cultures, were activated with antiCD3 mAbs, with or without anti-CD28 mAbs. After the indicated times, cells were collected and processed for analysis of FOXP3 mRNA and/or protein levels. FOXP3 mRNA was consistently induced after 24 hours of activation with anti-CD3 and anti-CD28 $\mathrm{mAbs}$, and protein was clearly detectable after 3 days (Figure 1B). However, the levels of mRNA or protein expression never reached those observed in $\mathrm{CD} 4{ }^{+} \mathrm{CD} 25^{+}$Tregs. Since $\mathrm{CD} 4^{+} \mathrm{CD} 25^{+}$Tregs express FOXP3 constitutively at high levels (Figure 1A), it seemed 

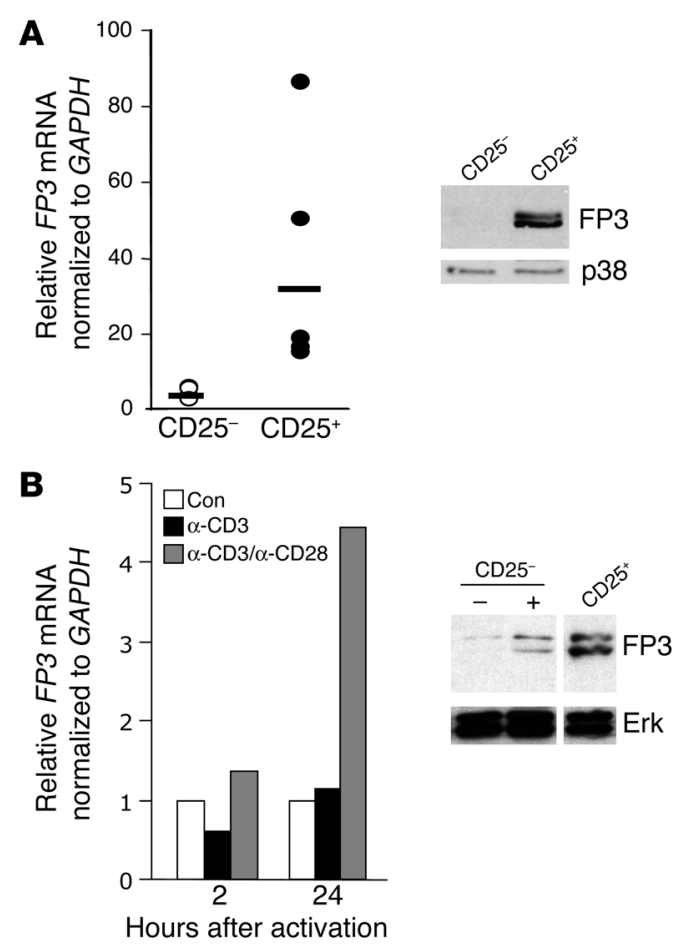

unlikely that this induced expression was due to the presence of a preexisting subset of Tregs within the $\mathrm{CD} 4^{+} \mathrm{CD} 25^{-} \mathrm{T}$ cell population. Further, expression of FOXP 3 in $\mathrm{CD} 4^{+} \mathrm{CD} 25^{+}$Tregs was found to either remain constant or decrease following activation (data not shown). Therefore, induction of FOXP3 in CD4 $4^{+} \mathrm{CD} 25^{-} \mathrm{T}$ cells could be due to the de novo differentiation of Tregs, as previously described (17), and/or FOXP3 behaving as an activation marker in human $\mathrm{CD}^{+} \mathrm{T}$ cells, as shown by Morgan et al. (19).

Ectopic expression of FOXP3 in human $\mathrm{CD}^{+} \mathrm{T}$ cells results in $\mathrm{T}$ cell byporesponsiveness and suppression of cytokines. Given the difficulty of gener-

\section{Figure 1}

Endogenous expression of FOXP3 (FP3) in human CD4+ T cells. CD4+ T cells were purified and separated into CD25- and CD25+ cells. (A) Expression of FOXP3 was determined by quantitative RT-PCR, with each point representing an individual donor, and Western blotting. (B) Highly purified $\mathrm{CD} 4{ }^{+} \mathrm{CD} 25^{-} \mathrm{T}$ cells were activated with immobilized anti-CD3 $(1 \mu \mathrm{g} / \mathrm{ml})$ and/or anti-CD28 $(1 \mu \mathrm{g} / \mathrm{ml})$ for the indicated times and assayed for mRNA expression. Levels of FOXP3 protein were determined after 3 days in cells left unstimulated $(-)$ or stimulated $(+)$ with anti-CD3 and anti-CD28. Protein levels were compared with those in ex vivo CD4+CD25+ Tregs. Results are representative of 5 experiments. Con, control.

ating homogenous populations of human $\mathrm{CD} 4^{+} \mathrm{CD} 25^{+}$Tregs (11), ectopic expression of FOXP3 potentially offered a rapid and convenient way to generate functional suppressor cells in vitro. Highly purified naive $\mathrm{CD} 4^{+} \mathrm{CD} 25^{-} \mathrm{CD} 45 \mathrm{RA}^{+} \mathrm{T}$ cells were transduced with a control retrovirus (LX) expressing truncated low-affinity nerve growth factor receptor ( $\triangle \mathrm{NGFR}$ ) or a FOXP3-encoding retrovirus, coexpressing $\triangle$ NGFR as a marker gene (Figure $2 \mathrm{~A}$ ). Populations of transduced cells with a purity greater than $95 \%$ were obtained by sorting for the $\triangle \mathrm{NGFR}$ marker with magnetic beads (Figure $2 \mathrm{~B}$ ). Note that insertion of a gene of interest in this vector routinely results in lower expression of the marker gene, and the lower mean fluorescence intensity (MFI) of $\triangle$ NGFR in the FOXP3-transduced cells does not reflect lower purity or toxic effects. Since existing antibodies did not allow us to reliably detect expression of FOXP3 by flow cytometry in human $\mathrm{T}$ cells, we also constructed a retroviral expression vector encoding $\mathrm{N}$-terminally HA-tagged FOXP3. Following infection of $\mathrm{CD}^{+} \mathrm{CD} 25^{-} \mathrm{CD} 45 \mathrm{RA}^{+} \mathrm{T}$ cells with the HAFOXP3-encoding virus, flow cytometric analysis demonstrated that $90-95 \%$ of $\triangle \mathrm{NGFR}^{+}$cells coexpressed FOXP3 (Figure 2C).

Quantitative RT-PCR revealed that the FOXP3-transduced T cells expressed approximately 25 -fold more FOXP3 mRNA than control (LX-transduced) cells (Figure 2D). This amount of FOXP3 mRNA is within the lower range of that found in ex vivo $\mathrm{CD} 4^{+} \mathrm{CD} 25^{+}$Tregs

\section{Figure 2}

Ectopic expression of FOXP3 in human CD4 ${ }^{+}$CD25-CD45RA ${ }^{+} T$ cells. (A) Control(LX-) or FOXP3- encoding retroviruses expressing $\triangle \mathrm{NGFR}$ as a marker gene were used for transduction of $\mathrm{CD} 4^{+} \mathrm{CD} 25^{-}$ CD45RA ${ }^{+} T$ cells. (B) Following purification, transduced $T$ cells were analyzed by flow cytometry. (C) In some cases, T cells were transduced with HA-tagged FOXP3, and coexpression of $\triangle \mathrm{NGFR}$ and FOXP3 was monitored by analysis of $\mathrm{HA}$ expression in $\triangle$ NGFR $^{+} T$ cells. (D) Quantitative RT-PCR and $(\mathrm{E})$ Western blotting were performed to determine expression levels of FOXP3. Ex vivo CD4+CD25- and CD4+CD25+ T cells were included to compare relative levels of expression. Results are representative of at least 8 tests with $\mathrm{T}$ cells derived from 3 different donors.
A LX- $\triangle$ NGFR

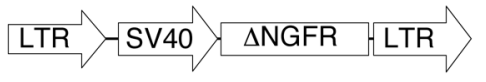

FP3- $\triangle$ NGFR
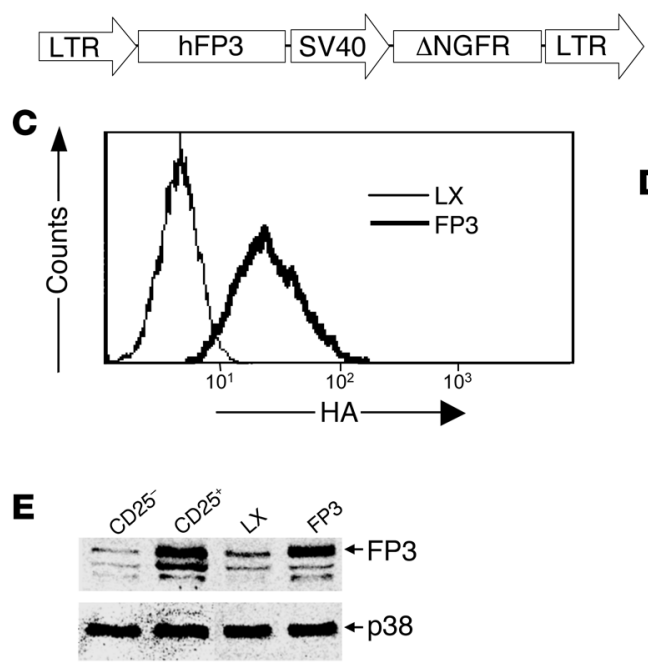
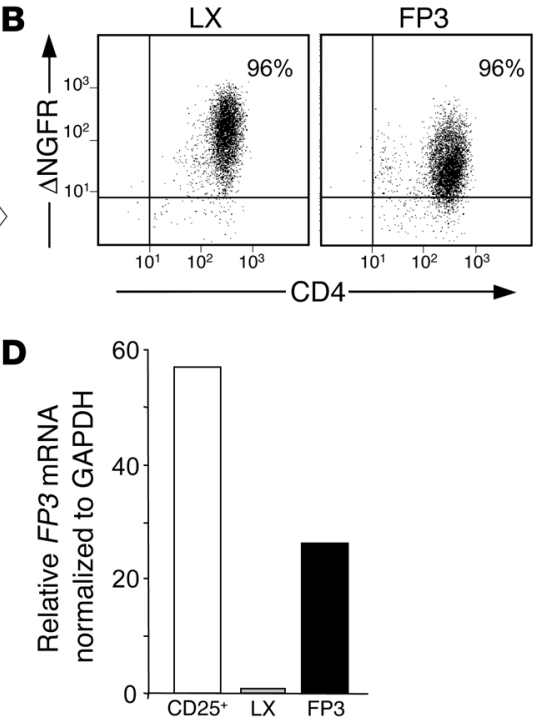

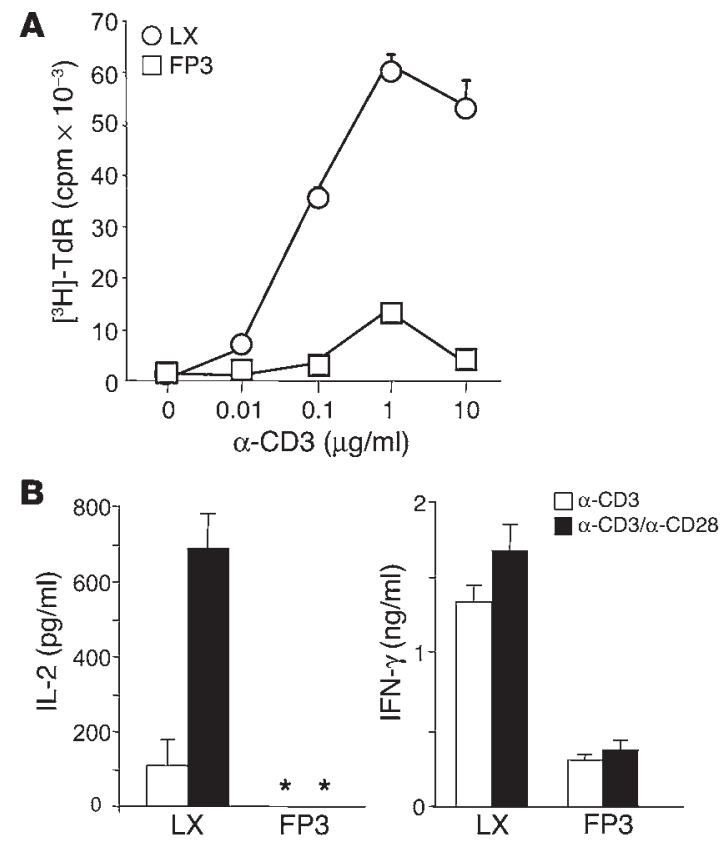

(Figure 1A) and compared with the $\mathrm{CD} 4^{+} \mathrm{CD} 25^{+}$Tregs from the donor used in Figure 2D is approximately 50\% lower. It should be noted that the primers used to quantitate levels of FOXP3 mRNA detect both full-length FOXP3 and a naturally occurring second splice isoform (discussed below).

Western blotting confirmed that FOXP3-transduced T cells also overexpressed the protein (Figure 2E) at levels comparable to that of $\mathrm{CD} 4{ }^{+} \mathrm{CD} 25^{+}$Tregs. Full-length FOXP3 corresponds to the upper band indicated in Figure 2E, while the identity of a second, lower band, which is also found in lysates of naturally occurring $\mathrm{CD} 4^{+} \mathrm{CD} 25^{+}$Tregs, is discussed below. The third band is nonspecific and not present in nuclear fractions. Control LXtransduced $\mathrm{T}$ cells also expressed detectable levels of FOXP3, reflecting the capacity of $\mathrm{CD} 4^{+} \mathrm{CD} 25^{-} \mathrm{T}$ cell populations to upregulate FOXP3 expression following activation and expansion, as described in Figure 1B.

Human $\mathrm{CD} 4{ }^{+} \mathrm{CD} 25^{+}$Tregs are hyporesponsive and do not produce detectable amounts of most cytokines, including IL-2 and IFN- $\gamma$ (11). We therefore investigated whether ectopic expression of FOXP3 resulted in a similar phenotype. FOXP3-transduced T

\section{Figure 4}

Ectopic expression of FOXP3 is not sufficient for suppressive function. (A) Autologous $\mathrm{CD}^{+} \mathrm{T}$ cells were stimulated with soluble anti-CD3 $\mathrm{mAbs}(1 \mu \mathrm{g} / \mathrm{ml})$ and APCs, in the presence or absence of control- (LX-) or FOXP3-transduced T cells, which were generated in the absence or presence of APCs, at a 1:1 or 2:1 (transduced cells/target cells) ratio. Ex vivo-isolated CD4 ${ }^{+} \mathrm{CD} 25^{+}$Tregs were added as a positive control. (B) In parallel experiments, proliferation of CFSE-labeled autologous CD4 ${ }^{+} \mathrm{T}$ cells, alone or in the presence of a 1:1 ratio of control- (LX-) or FOXP3-transduced T cells, or ex vivo CD4+CD25+ (CD25+) Tregs was analyzed by flow cytometry after 96 hours. Numbers represent the percentage of undivided cells in the cultures. (C) Culture supernatants were collected and analyzed by cytometric bead assay to determine amounts of IL-2 (after 36 hours) or IFN- $\gamma$ (after 72 hours). Results are representative of 4 independent experiments for $\mathbf{A}$ and $\mathbf{3}$ for $\mathbf{B}$ and $\mathbf{C}$. The asterisks indicate less than $9 \mathrm{pg} / \mathrm{ml}$.

\section{Figure 3}

Proliferative capacity and cytokine production profile of FOXP3-transduced T cells. (A) Transduced T cells were tested for their ability to proliferate in response to increasing concentrations of immobilized antiCD3 mAbs, based on incorporation of tritiated thymidine $\left(\left[{ }^{3} \mathrm{H}\right] \mathrm{TdR}\right) .(\mathrm{B})$ T cells were stimulated with anti-CD3 mAbs $(1 \mu \mathrm{g} / \mathrm{ml})$, with or without anti-CD28 mAbs ( $1 \mu \mathrm{g} / \mathrm{ml})$, for 24 hours (IL-2) and 48 hours (IFN- $\gamma$ ). The asterisk indicates less than $9 \mathrm{pg} / \mathrm{ml}$. Culture supernatants were analyzed by ELISA. Data are representative of 5 independent experiments for $\mathbf{A}$ and 3 for $\mathbf{B}$.

cells were hyporesponsive upon TCR-mediated activation (Figure 3A). This hyporesponsiveness of FOXP3-transduced T cells, like that of $\mathrm{CD} 4^{+} \mathrm{CD} 25^{+}$Tregs (4), was reversed by addition of exogenous IL-2 (data not shown).

In addition to being hyporesponsive, FOXP3-transduced T cells had a significantly reduced capacity to produce IL-2 upon activation in comparison with controls $(P \leq 0.006 ; n=9$; Figure $3 \mathrm{~B})$. Moreover, similar to $\mathrm{CD} 4^{+} \mathrm{CD} 25^{+}$Tregs, they were also impaired in their capacity to produce IFN- $\gamma$, although this suppression bordered on significance since it was found to be variable among donors and less potent than that of IL-2 $(P \leq 0.06$; $n=9$; Figure 3B).
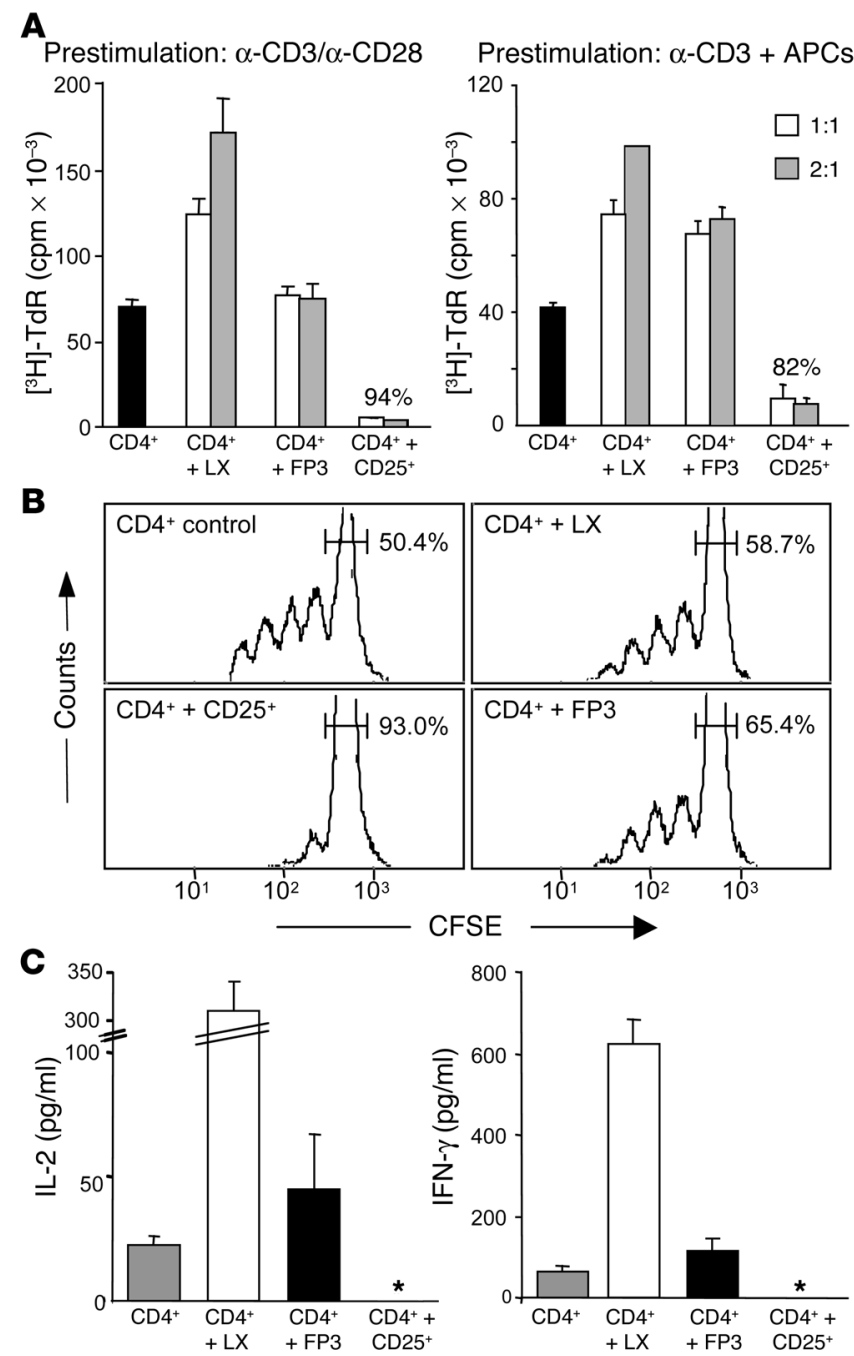
A

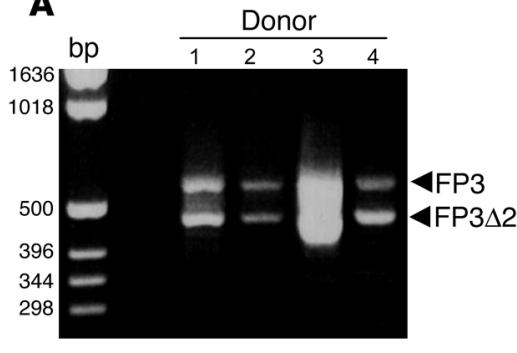

Figure 5

Two isoforms of FOXP3 in human $\mathrm{CD} 4{ }^{+} \mathrm{CD} 25^{+}$Tregs with repressor activity. (A) RNA was extracted from purified CD4+CD25+ cells of normal donors and analyzed by RT-PCR using primers specific for a region of FOXP3 spanning exons 1 and 3 . (B) Jurkat $T$ cells were cotransfected with an hIL-2-luciferase reporter, $\beta$-galactosidase, and either control- (LX-), FOXP3-, or FOXP3 $\triangle 2$ - (FP3 $\triangle 2-$-) encoding plasmids. Following stimulation with $\mathrm{PMA}$ and $\mathrm{Ca}^{2+}$ ionophore, luciferase activity was determined and normalized to amounts of $\beta$-galactosidase activity. The graph depicts the percent activity of the reporter in comparison to the LX-transfected control. Data represent the average of 5 independent experiments.

Ectopic expression of FOXP3 in buman $\mathrm{CD}^{+} \mathrm{T}$ cells does not result in acquisition of suppressive activity. We next investigated whether ectopic expression of FOXP3 was sufficient to generate a population of cells with suppressive activity in vitro. Autologous $\mathrm{CD}^{+} \mathrm{T}$ cells were activated with anti-CD3 $\mathrm{mAbs}$ and APCs in the absence or presence of control-transduced or FOXP3-transduced $\mathrm{CD}^{+} \mathrm{T}$ cells. FOXP3-transduced $\mathrm{CD} 4^{+} \mathrm{T}$ cells did not suppress the proliferation of autologous $\mathrm{CD}^{+} \mathrm{T}$ cells when added at a $1: 1$ or $2: 1$ ratio (Figure 4A, left panel). Similar results were obtained in cultures activated with phytohemagluttinin or alloantigens (data not shown). In contrast, ex vivo-isolated $\mathrm{CD} 4^{+} \mathrm{CD} 25^{+}$Tregs potently suppressed proliferation. We also investigated whether the activation conditions used prior to transduction may be important for the development of suppressive T cells. However, parallel experiments involving prestimulation in the presence of APCs also failed to induce a population of suppressive $T$ cells upon ectopic expression of FOXP3 (Figure 4A, right panel).

\section{Figure 6}

Retroviral transduction of $\mathrm{CD} 4{ }^{+} \mathrm{CD} 25^{-}$ CD45RA ${ }^{+} T$ cells with FOXP3 2 in the absence or presence of FOXP3. (A) Control(LX-) or FOXP3 $\triangle 2$-encoding retroviral vectors expressing GFP as a marker gene were used in combination with $\triangle$ NGFR-expressing retroviral vectors (see Figure $2 \mathrm{~A}$ ) for double transduction of $\mathrm{CD} 4{ }^{+} \mathrm{CD} 25-\mathrm{CD} 45 \mathrm{RA}{ }^{+} \mathrm{T}$ cells. Following FACS sorting and expansion, transduced T cells were analyzed by flow cytometry (B), quantitative RT-PCR (C), and Western blotting (D). Results are representative of $T$ cells derived from 3 different donors.

A LX-GFP

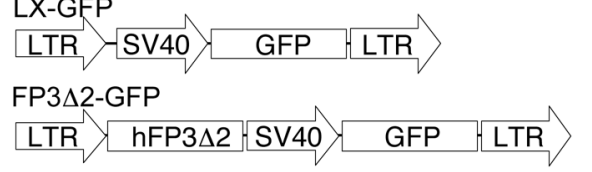

B

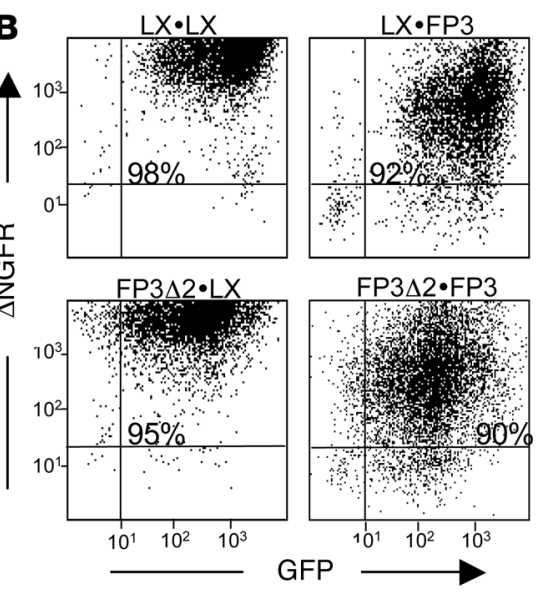

Interestingly, the net proliferation in cocultures of $\mathrm{CD} 4^{+} \mathrm{T}$ cells and FOXP3-transduced $\mathrm{T}$ cells was on average approximately $37 \%$ lower $(P \leq 0.013 ; n=7)$ than that in cocultures with controltransduced $\mathrm{T}$ cells. To exclude the possibility that this was due to a combination of suppressed proliferation of the $\mathrm{CD} 4^{+} \mathrm{T}$ cells and enhanced proliferation of the FOXP3-expressing $\mathrm{T}$ cells, we labeled the $\mathrm{CD}^{+} \mathrm{T}$ cells with CFSE and independently assessed their proliferation. Coculture with control- or FOXP3-transduced T cells did not significantly alter the capacity of the CFSE-labeled CD4 $4^{+} \mathrm{T}$ cells to divide (Figure 4B). In contrast, freshly isolated $\mathrm{CD} 4^{+} \mathrm{CD} 25^{+}$ Tregs potently suppressed their division.

In some cases $\mathrm{CD} 4^{+} \mathrm{CD} 25^{+}$Tregs may suppress effector functions but not proliferation (20). We therefore tested whether FOXP3-transduced $\mathrm{T}$ cells could alter cytokine production by the targets of suppression. As shown in Figure 4C, neither control- nor FOXP3-transduced T cells suppressed secretion of IL- 2 by $\mathrm{CD} 4^{+} \mathrm{T}$ cells upon activation with anti-CD3 and APCs. In contrast, freshly isolated $\mathrm{CD} 4{ }^{+} \mathrm{CD} 25^{+}$Tregs potently suppressed production of IL-2. Similar results were obtained upon analysis of IFN- $\gamma$ production upon activation with anti-CD3 and APCs (Figure 4C). Thus, although FOXP3-transduced $\mathrm{CD}^{+} \mathrm{T}$ cells are hyporesponsive, they do not possess a suppressive activity that is detectable in vitro.

Human $\mathrm{CD}^{+} \mathrm{CD} 25^{+}$Tregs coexpress 2 isoforms of FOXP3. During the isolation of the human FOXP3 (hFOXP3) cDNA by RT-PCR from mRNA from $\mathrm{CD} 4{ }^{+} \mathrm{CD} 25^{+}$Tregs, we noted that several clones encoded a version that completely lacked the second coding exon $(F O X P 3 \Delta 2)(18,21)$. We therefore investigated whether the mRNA for this second, presumably alternatively spliced, isoform was consistently expressed in all donors. As shown in Figure 5A, RT-PCR revealed that both isoforms were uniformly expressed in $\mathrm{CD} 4^{+} \mathrm{CD} 25^{+}$Tregs from all donors tested. Deletion of exon 2 is predicted to result in an approximately $4-\mathrm{kDa}$ decrease in the molecular weight of FOXP3, offering an explanation for the identity of the second (lower) band detected in lysates from human $\mathrm{CD} 4^{+} \mathrm{CD} 25^{+}$Tregs (Figure 1 ).

Exon 2 is in a region of FOXP3 that is relatively uncharacterized and does not contain any known protein domains. We were there- 
A

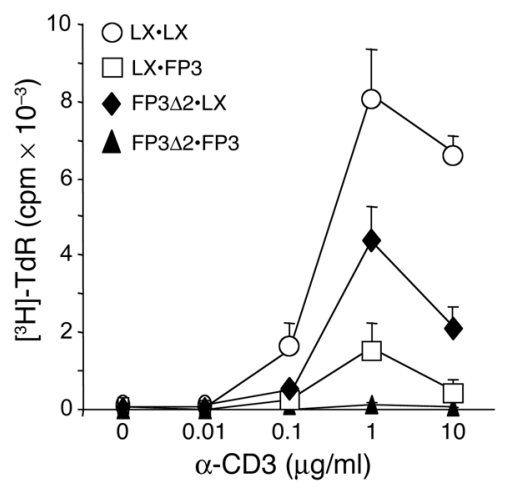

B

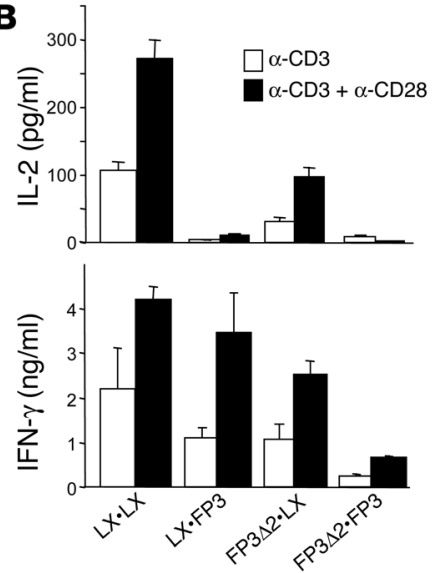

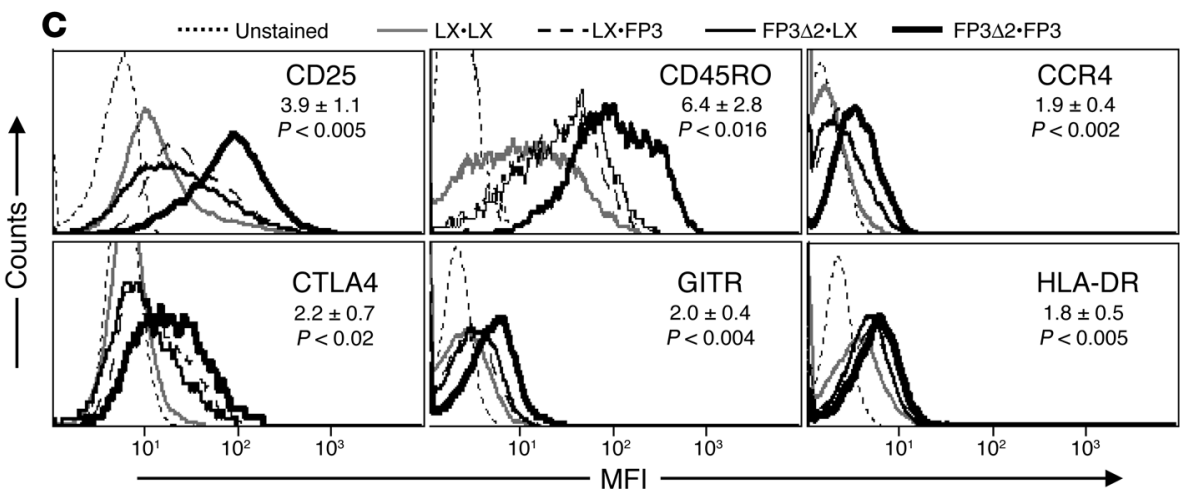

Figure 7

Proliferative capacity, cytokine production, and cell-surface phenotype of cells expressing FOXP $3 \triangle 2$ in the absence or presence of FOXP3. (A) Transduced T cells were tested for their ability to proliferate in response to increasing concentrations of immobilized anti-CD3 mAbs. (B) T cells were stimulated with anti-CD3 mAbs $(1 \mu \mathrm{g} / \mathrm{ml})$, with or without anti-CD28 mAbs $(1 \mu \mathrm{g} / \mathrm{ml})$, for 24 hours (IL-2) and 48 hours (IFN- $\gamma$ ). Culture supernatants were analyzed by ELISA. (C) Expression levels of the indicated proteins was determined in the resting phase. Numbers indicate the average fold increase in MFI in the FP3 $\triangle 2 \cdot F P 3 T$ cells compared with the $L X \cdot L X$ controls. Data are representative of a minimum of 6 independent experiments with $\mathrm{T}$ cells derived from 2 different donors. fore interested to know whether FOXP3 $\Delta 2$ acts as a transcriptional repressor protein. Transient transfection assays in Jurkat $\mathrm{T}$ cells were performed to assess the relative capacity of FOXP3 and FOXP3 $\Delta 2$ to suppress activation of the hIL-2 promoter. As expected, coexpression of FOXP3 resulted in a significant decrease in IL-2 promoter activity following activation with PMA and $\mathrm{Ca}^{2+}$ ionophore (Figure 5B). The fold decrease in promoter activity, although highly significant, was somewhat less than previously reported (22), possibly because the native human IL-2 promoter was used in the current study rather than a multimer of a nuclear factor of activated T cells (NFAT) regulatory site from the mouse IL-2 promoter. Importantly, coexpression of FOXP3 32 with the IL-2 reporter gene resulted in identical suppression of promoter activity. Thus, the FOXP $3 \Delta 2$ isoform also appears to be a transcriptional repressor protein.

Biological effects of ectopic expression of FOXP $3 \triangle 2$ in the absence or presence of FOXP3. Given our unexpected finding that ectopic expression of FOXP3 in human $\mathrm{CD}^{+} \mathrm{CD} 25^{-} \mathrm{CD} 45 \mathrm{RA}^{+} \mathrm{T}$ cells was not sufficient to induce a potent suppressor cell phenotype, we investigated whether coexpression of the FOXP $3 \Delta 2$ isoform may be required. A new series of retrovirus-based vectors was generated that encoded FOXP3 $\Delta 2$, and GFP as a marker gene in place of $\triangle$ NGFR (Figure $6 \mathrm{~A}) . \mathrm{CD}^{+} \mathrm{CD} 25^{-} \mathrm{CD} 45 \mathrm{RA}^{+} \mathrm{T}$ cells were then simultaneously transduced with: LX-GFP and LX- $\triangle$ NGFR alone $(\mathrm{LX} \bullet \mathrm{LX})$; LX-GFP and FOXP3- $\triangle$ NGFR $(\mathrm{LX} \bullet \mathrm{FP} 3$ ); FOXP3 $\Delta 2$-GFP and LX- $\Delta$ NGFR $(F P 3 \Delta 2 \bullet$ LX); or FOXP $3 \Delta 2$-GFP and FOXP3$\Delta$ NGFR $(\mathrm{FP} 3 \Delta 2 \bullet \mathrm{FP} 3)$. Five to 6 days after transduction, double $\Delta \mathrm{NGFR}^{+} \mathrm{GFP}^{+}$cells were sorted by flow cytometry to purities greater than $90 \%$ (Figure 6B). As discussed above, the lower MFIs of $\triangle \mathrm{NGFR}$ and GFP in the FOXP3 and/or FOXP3 $\Delta 2$ cells reflect the presence of a second cDNA upstream of the marker genes.
We confirmed that the various populations of transduced cells expressed high levels of FOXP3 mRNA and protein. Figure 6C shows that the FP3 $\triangle 2 \bullet \mathrm{FP} 3 \mathrm{~T}$ cells expressed levels of mRNA that were approximately 140 -fold higher than those of controls. These levels are within the higher range of the amounts of FOXP3 mRNA detected in freshly isolated $\mathrm{CD} 4^{+} \mathrm{CD} 25^{+}$Tregs (Figure $1 \mathrm{~A}$ ). Western blotting revealed overexpression of FOXP3 and/or FOXP $3 \Delta 2$ protein to levels that appear higher than those in $\mathrm{CD} 4^{+} \mathrm{CD} 25^{+}$Tregs (Figure 6D). Further, the molecular weight of the FP3 2 isoform appears identical to that of the second band in $\mathrm{CD} 4{ }^{+} \mathrm{CD} 25^{+}$Tregs, further supporting our hypothesis regarding its identity. As in Figure $2 \mathrm{E}$, the LX $\bullet \mathrm{LX}$ control $\mathrm{T}$ cell line also expressed detectable levels of both isoforms of FOXP3 due to activation-induced expression (Figure 6D).

The transduced $\mathrm{T}$ cell lines were next tested to determine their biological phenotype. Although ectopic expression of FOXP3 $\Delta 2$ also resulted in induction of hyporesponsiveness, the antiproliferative effect was significantly lower than that in cells overexpressing FOXP3 (Figure 7A). Whereas FOXP3-transduced cells proliferated at a rate of $30 \% \pm 11 \%$ compared with controls, FOXP3 $\Delta 2$-transduced cells proliferated at $64 \% \pm 41 \%(n=5 ; 1 \mu \mathrm{g} / \mathrm{ml}$ anti-CD3). In contrast, FP $3 \Delta 2 \bullet \mathrm{FP} 3 \mathrm{~T}$ cells were found to be profoundly hyporesponsive and failed to proliferate over the entire range of doses of anti-CD3 mAbs tested. A similar pattern was observed upon analysis of IL-2 production. Overexpression of FOXP3 $\Delta 2$ only moderately reduced IL-2 production in comparison to FOXP3 $\mathrm{T}$ cells, whereas FP3 $\Delta 2 \bullet \mathrm{FP} 3 \mathrm{~T}$ cells displayed a complete block $(P \leq 0.004$ in comparison to $\mathrm{LX} \bullet \mathrm{LX}$ control; $n=7$; Figure $7 \mathrm{~B})$. Further, only when both FOXP3 and FOXP3 $\Delta 2$ were coexpressed was there consistent and strong suppression of IFN- $\gamma$ production $(P<0.009$ compared with control; $n=6)$. 


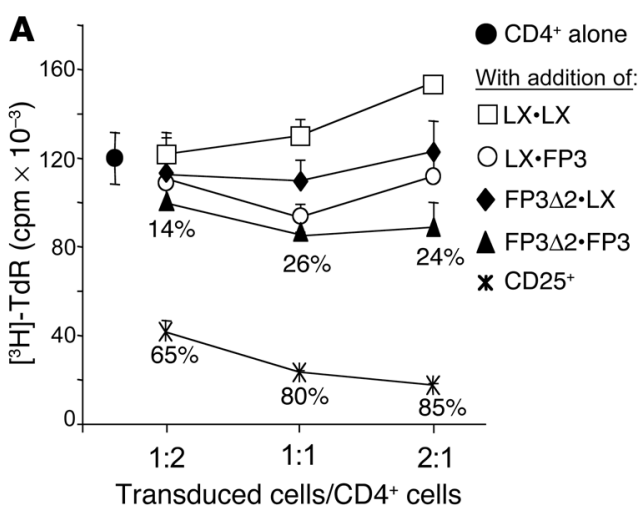

Transduced cells/CD4+ cells

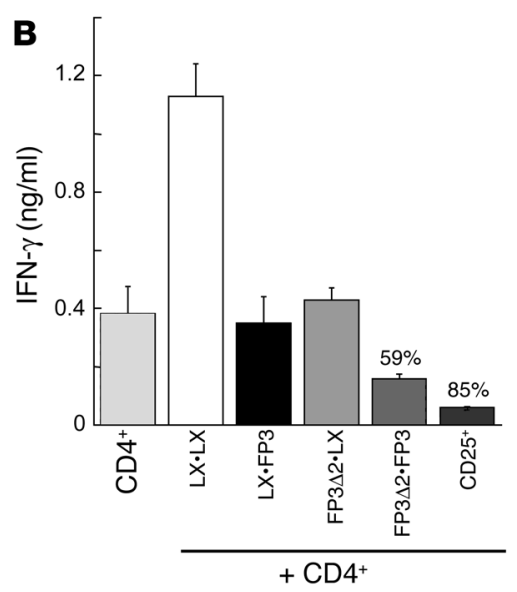

Figure 8

Coexpression of FOXP3 and FOXP3 32 is not sufficient for acquisition of suppressor activity at levels equivalent to CD4+CD25+ Tregs. (A) Autologous CD4+ $\mathrm{T}$ cells were stimulated with soluble anti-CD3 mAbs $(1 \mu \mathrm{g} / \mathrm{ml})$ and APCs, in the presence or absence of double-transduced T cells at increasing transduced cell/target cell ratios. Ex vivo-isolated CD4+CD25+ Tregs were added as a positive control. (B) Culture supernatants were collected and analyzed by cytometric bead assay to determine amounts of IFN- $\gamma$ after 72 hours. Numbers represent the percent suppression compared with $\mathrm{CD} 4^{+} \mathrm{T}$ cells alone. For $\mathbf{A}$, data are representative of 3 experiments where suppression at a $1: 1$ ratio was observed (out of a total of 7 ). $\mathbf{B}$ is representative of 4 independent experiments. function of naive human $\mathrm{CD}^{+} \mathrm{T}$ cells. Although overexpression of FOXP3 alone induced hyporesponsiveness and suppression of cytokine production, it did not result in detectable suppressive capacity in vitro. Overexpression of FOXP3 $\Delta 2$ resulted in a similar phenotype, but with less potent suppression of IL-2 and induction of anergy. Importantly, coexpression of both isoforms of FOXP3, at levels equal to, or greater than, those in $\mathrm{CD} 4^{+} \mathrm{CD} 25^{+}$ Tregs, resulted in profound suppression of IL- 2 and IFN- $\gamma$ production, induction of hyporesponsiveness, and significant upregulation of several Treg-associated markers. However, the suppressive capacity of FOXP3 $3^{+} \mathrm{FOXP} 3 \Delta 2^{+} \mathrm{T}$ cells was variable and modest in comparison to that of ex vivo $\mathrm{CD} 4{ }^{+} \mathrm{CD} 25^{+}$Tregs. These data, together with the finding that $\mathrm{CD}^{+} \mathrm{CD} 25^{-} \mathrm{T}$ cells upregulate FOXP3 following activation, suggest that expression of FOXP3 may be necessary but not sufficient for the generation of bona fide human $\mathrm{CD} 4^{+} \mathrm{CD} 25^{+}$Tregs from naive $\mathrm{CD}^{+} \mathrm{T}$ cells in vitro.

Finally, we investigated the cell-surface phenotype of doubletransduced $T$ cells in the resting state to determine whether any Treg-associated cell-surface markers were elevated upon overexpression of FOXP3. Although expression of FOXP3 or FOXP3 42 alone caused a minor upregulation of some markers, coexpression of both isoforms resulted in a significant elevation of CD25, CD45RO, CCR4, CTLA4, GITR, and HLA-DR (Figure 7C). We also investigated CD122 (IL-2R $\beta$ ) but found the increase in expression of this protein to be highly variable between experiments (data not shown). Thus, upon coexpression of FOXP3 and FOXP3 $\Delta 2$, T cells acquire the bona fide cell-surface phenotype of $\mathrm{CD} 4{ }^{+} \mathrm{CD} 25^{+}$Tregs.

Coexpression of FOXP 3 and FOXP $3 \triangle 2$ in buman $C D 4^{+} T$ cells results in acquisition of modest suppressive activity. We then tested the transduced $\mathrm{T}$ cells for their capacity to suppress T cell responses. Surprisingly, even the FP3 $\Delta 2 \bullet \mathrm{FP} 3 \mathrm{~T}$ cells failed to consistently and significantly suppress proliferation of $\mathrm{CD}^{+} \mathrm{T}$ cells (Figure $8 \mathrm{~A}$ ). We observed suppression at a 1:1 ratio in only 3 of 7 experiments, and of these 3 , the average reduction in proliferation was only $36 \% \pm 10 \%$. In contrast, in all experiments, ex vivo $\mathrm{CD} 4^{+} \mathrm{CD} 25^{+}$Tregs potently suppressed proliferation, on average by $86 \% \pm 7 \%(n=6)$.

Finally, we determined whether FP3 $\Delta 2 \bullet \mathrm{FP} 3 \mathrm{~T}$ cells were capable of suppressing IFN- $\gamma$ production. Addition of cells overexpressing FOXP3 or FOXP3 $\Delta 2$ alone did not significantly affect production of IFN- $\gamma$ by CD $4^{+} \mathrm{T}$ cells. In contrast, a consistent and significant effect was observed in the presence of FP $3 \Delta 2 \bullet \mathrm{FP} 3 \mathrm{~T}$ cells, and IFN $\gamma$ was suppressed in all experiments by an average of $49.5 \% \pm 19 \%$. However, this average suppression of approximately $50 \%$ was less profound than that mediated by highly purified $\mathrm{CD} 4^{+} \mathrm{CD} 25^{+}$Tregs, which suppressed IFN- $\gamma$ production by an average of $82 \% \pm 7 \%$ (Figure $8 B$ ).

\section{Discussion}

We used a retrovirus-based overexpression strategy to investigate the capacity of FOXP3 and FOXP $3 \Delta 2$ to alter the phenotype and
Unlike murine Tregs, we found that human $\mathrm{CD} 4^{+} \mathrm{CD} 25^{+}$Tregs coexpress equal amounts of 2 isoforms of FOXP3: one corresponding to the canonical full-length sequence; and the other lacking the sequence encoded by exon $2(18,21)$. The function of the FOXP3 $\Delta 2$ isoform remains to be fully defined, but our data indicate that it also possesses transcriptional repressor activity toward the IL-2 promoter (Figure 5B). However, the finding that FOXP $3 \Delta 2^{+} \mathrm{T}$ cells were less hyporesponsive (Figure 7A) and produced more IL-2 (Figure 7B) than $\mathrm{FOXP}^{+} \mathrm{T}$ cells suggests that the 2 isoforms may have distinct

Ectopic expression of FOXP3 and/or FOXP $3 \Delta 2$ results in $\mathrm{T}$ cell hyporesponsiveness and reduced IL-2 production (Figures 3 and 7). The ability of exogenous IL-2 to reverse hyporesponsiveness (data not shown) suggests that defective autocrine production of this cytokine limits proliferative capacity of FOXP3-transduced cells. These findings are consistent with the hypothesis that FOXP3 can directly suppress IL-2 transcription (Figure 5B) by interfering with NFAT activity (22) and support recent findings by Yagi et al. (18).

Importantly, coexpression of both isoforms of FOXP3 resulted in significantly increased suppression of cytokines and proliferation as well as upregulation of several Treg-associated markers to levels comparable to those found on ex vivo $\mathrm{CD} 4{ }^{+} \mathrm{CD} 25^{+}$Tregs (Figure 7 C) $(4,11,12)$. However, since a functional role has not been defined for any of these cell-surface molecules, their increased expression is not necessarily indicative of suppressive capacity. For example, although high CD25 expression is correlated with suppressor activity, it is not sufficient (11). Nevertheless, the fact that coexpression of FOXP 3 and FOXP3 2 results in the most significant changes in T cell phenotype suggests that the 2 isoforms may work in concert at the molecular level to influence transcription of these Treg-associated genes.

We were able to detect regulatory activity in the FOXP3 ${ }^{+} \mathrm{FOXP} 3 \Delta 2^{+}$ transduced $T$ cells, but their suppressive capacity, as measured by reduction in proliferation, was variable and when present was on functions in vivo. 
average $36 \%$ at a $1: 1$ ratio (Figure $8 \mathrm{~A}$ ). When measured by reduction of IFN- $\gamma$ production, addition of a $1: 1$ ratio of FOXP $3^{+} \mathrm{FOXP} 3 \Delta 2^{+}-$ transduced $\mathrm{T}$ cells resulted in an average of $50 \%$ suppression (Figure 8B). Although Yagi et al. did not report statistical analyses for their suppression assays, they found that addition of a 1:1 ratio of single-transduced $\mathrm{FOXP}^{+} \mathrm{T}$ cells reduced proliferation by approximately $60 \%$ (18). In our study, only when both isoforms of FOXP3 were overexpressed was a similar suppressive capacity induced. However, this $50-60 \%$ suppression is less profound than that mediated by pure populations of ex vivo $\mathrm{CD} 4^{+} \mathrm{CD} 25^{+}$Tregs, which consistently suppress proliferation by an average of $86 \%$ and production of IFN- $\gamma$ by an average of $82 \%$ at a $1: 1$ ratio. Such moderately potent Treg populations would likely not be suitable for cellular therapy. Thus, although it seems likely that FOXP3 is involved in the development of human $\mathrm{CD} 4^{+} \mathrm{CD} 25^{+}$Tregs, it does not appear to be the sole master switch that can transform human $\mathrm{CD}^{+} \mathrm{T}$ cells in vitro into suppressor cells that are functionally equivalent to $\mathrm{CD} 4{ }^{+} \mathrm{CD} 25^{+}$Tregs.

The fact that overexpression of FOXP3 alone was not sufficient to induce significant upregulation of Treg-associated cell-surface markers or detectable suppressive activity was surprising in view of several reports from mouse models (14-16) and 2 studies carried out with human cells $(18,23)$. We considered the possibility that we simply failed to express sufficient FOXP3 to achieve the predicted biological effects. However, Yagi et al. reported that overexpression of FOXP3 mRNA at levels 70\% lower than those found in $\mathrm{CD} 4{ }^{+} \mathrm{CD} 25^{+}$Tregs (protein levels were not directly compared) was sufficient to induce a suppressive phenotype (18). In our system, quantitative RT-PCR and Western blotting revealed that FOXP3-transduced $T$ cells expressed full-length FOXP3 at levels in the range of those detected in $\mathrm{CD} 4^{+} \mathrm{CD} 25^{+}$Tregs (Figure 2, D and E, and Figure 6, C and D) and that appear to be higher than those reported in the study by Yagi et al. Moreover, expression levels of $\triangle$ NGFR and cell purities seem to be comparable in the 2 studies. These data, along with our demonstration that $90-95 \%$ of $\Delta \mathrm{NGFR}^{+} \mathrm{T}$ cells coexpress FOXP3 (Figure $2 \mathrm{C}$ ), lead us to conclude that the discrepancy between our findings and those of Yagi et al. (18) and Oswald-Richter et al. (23) are not the result of insufficient cell purity or expression of FOXP3. Rather, we believe that the overall conclusion from these 3 studies is that although ectopic expression of FOXP3, with or without FOXP $3 \Delta 2$, results in acquisition of a certain degree of suppressor activity, these cells do not fully recapitulate the function of $\mathrm{CD}^{+}{ }^{+} \mathrm{CD} 25^{+}$Tregs, at least in vitro. Nevertheless, it remains possible that in vivo these cells may be potently suppressive. Evidence that the in vitro and in vivo phenotype and/or function of $\mathrm{CD} 4{ }^{+} \mathrm{CD} 25^{+}$Tregs may not be strictly correlated includes the finding that despite their hyporesponsive state in vitro, they do proliferate in vivo, and a number of discrepancies may relate to mechanistic dependence on cytokines (24). In addition, in the context of transplantation, Tregs do not detectably alter proliferation or cytokine production ex vivo but clearly induce functional tolerance in vivo $(25,26)$.

In view of recent reports highlighting the importance of costimulatory molecules in Treg development (27), we also investigated whether APCs may be required during the Treg development process. We therefore performed parallel retroviral transductions in the presence of autologous APCs (18) but found that despite induction of hyporesponsiveness and suppression of cytokine production (data not shown), the resulting FOXP3 ${ }^{+} \mathrm{T}$ cells did not acquire significant suppressive activity (Figure 4A). In addition, the transduction method described by Oswald-Richter et al. involved prestimulation in the absence of APCs, and regulatory activity in the resulting population was reported (23). However, the function of the transduced cells in the latter study may have been influenced by expansion with Staphylococcus enterotoxin B, an agent that is known to promote the development of suppressive T cells $(28,29)$. Thus, the presence of APCs during ectopic FOXP3 expression in $\mathrm{CD}^{+} \mathrm{CD} 25^{-} \mathrm{CD} 45 \mathrm{RA}^{+} \mathrm{T}$ cells does not appear to be critical for induction of Tregs.

It is possible that peripheral blood $\mathrm{CD}^{+} \mathrm{T}$ cells that are susceptible to retroviral infection are refractory to the full Treg-inducing effects of FOXP3. It is also possible that naive $\mathrm{CD}^{+}{ }^{+} \mathrm{T}$ cells from adult peripheral blood are in a state of differentiation that prevents them from becoming fully functional upon overexpression of FOXP3 and/or FOXP3 $\Delta 2$. Alternatively, we favor the hypothesis that activation of human $\mathrm{CD}^{+} \mathrm{T}$ cells prior to transduction, which results in upregulation of both isoforms of endogenous FOXP3 (Figure 1) (17), may lead to changes in gene expression that modulate the function of FOXP3 to ensure that the majority of cells retain their effector function. Indeed, data suggesting that, in contrast to murine cells (14-16), FOXP3 is an activation marker in human $\mathrm{CD}^{+} \mathrm{T}$ cells and $\mathrm{T}$ cell clones (Figure 1$)(19,30)$, imply that this transcription factor may be subjected to differential regulation in the 2 species.

Notably, CD4 ${ }^{+} \mathrm{CD} 25^{-} \mathrm{T}$ cells isolated from Foxp3-transgenic mice show significantly increased expression of GITR yet display minimal regulatory activity compared with wild-type $\mathrm{CD} 4^{+} \mathrm{CD} 25^{+}$ Tregs (14). Moreover, $\mathrm{CD} 4^{+} \mathrm{CD} 25^{+}$Tregs from Foxp3-transgenic mice are actually less suppressive than their wild-type counterparts on a per cell basis (14). In addition, normal expression of FOXP3 was found in functionally defective CD $4^{+} \mathrm{CD} 25^{+}$Tregs from patients with autoimmune polyglandular syndrome type II (31). We and others have also found that activated nonsuppressive T cell clones express significant amounts of FOXP3 (our unpublished data and ref. 30). Finally, HIV-infected patients who have been treated with IL-2 develop a population of cells that express high levels of FOXP3 but exert a weak suppressive function (32). These findings strongly support our interpretation that factors in addition to FOXP3 are required during the process of activation and/or differentiation for the development of bona fide Tregs, as also suggested by Fontenot and Rudensky (33).

In conclusion, evidence that human $\mathrm{CD} 4^{+} \mathrm{CD} 25^{+}$Tregs express high levels of FOXP3 (Figure 1) $(17,18)$, and that mutation of FOXP3 results in the development of severe autoimmunity (13), clearly indicates that this transcription factor has a key role in immune homeostasis. Analysis of $\mathrm{CD} 4^{+} \mathrm{CD} 25^{+} \mathrm{T}$ cells from patients with IPEX will be important to define the role of FOXP3 in human Treg development and function. Our parallel study of 2 IPEX patients revealed that functional CD $4^{+} \mathrm{CD} 25^{+}$Tregs are present in these children (R. Bacchetta et al., manuscript submitted for publication), further supporting the conclusion that the role of FOXP3 in mice and humans may not be identical. Characterization of other proteins that interact with FOXP3 and the genes it regulates will be necessary to understand its true biological function. While ectopic expression of FOXP3 alone, or together with FOXP $3 \Delta 2$, may not be an effective means of generating large numbers of human Tregs for cellular therapy, this protein is clearly a link in the regulatory circuit that controls immunological tolerance. 


\section{Methods}

Cell purification. Peripheral blood was obtained from healthy volunteers following approval of the protocol by the University of British Columbia Clinical Research Ethics Board and after obtaining written informed consent from individual donors. $\mathrm{CD}^{+} \mathrm{T}$ cells were purified by negative selection from PBMCs with magnetic beads (Miltenyi Biotec). $\mathrm{CD} 25^{+}$cells were purified by positive selection over 2 columns (Miltenyi Biotec) to ensure $85-90 \%$ purity. To obtain pure (>95\%) CD4+CD25- T cells, the CD25- fraction was either passed over an LD depletion column (Miltenyi Biotec) or FACS sorted. For isolation of CD $4^{+} \mathrm{CD} 25^{-} \mathrm{CD} 45 \mathrm{RA}^{+} \mathrm{T}$ cells, $\mathrm{CD} 4^{+} \mathrm{CD} 25^{-} \mathrm{T}$ cells were incubated with CD45RO beads (Miltenyi Biotech) and passed over an LD depletion column. Purity of $\mathrm{CD} 4{ }^{+} \mathrm{CD} 25^{-} \mathrm{CD} 45 \mathrm{RA}^{+}$cells was greater than $95 \%$.

Isolation of hFOXP 3 and RT-PCR. hFOXP3 and hFOXP3 42 were amplified from cDNA using 5'-GCCCTTGGACAAGGACCCGATG-3' as the sense and $5^{\prime}$-TCAGGGGCCAGGTGTAGGGTTG- 3 ' as the antisense primers. The integrity of the cloned cDNAs was verified by DNA sequencing. For non-quantitative RT-PCR to asses expression of FOXP3 and FOXP3 $\triangle 2$, the above-mentioned sense oligonucleotide was used together with the 5'-CATTTGCCAGCAGTGGGTAGGA-3' antisense oligonucleotide. For quantitative RT-PCR, amounts of FOXP3 and GAPDH mRNA were determined using Assay on Demand real-time PCR kits (Applied Biosystems) with TaqMan Master Mix (QIAGEN). Samples were run in triplicate, and relative expression of FOXP3 was determined by normalizing to GAPDH expression in order to calculate a fold change in value.

Western blotting. Whole cell lysates were prepared by sonication in lysis buffer containing 1\% SDS, $10 \mathrm{mM}$ HEPES, and 2 mM EDTA ( $\mathrm{pH}$ 7.4). Alternatively, nuclear lysates were prepared using an NE-PER Nuclear and Cytoplasmic Extraction Kit (Pierce Biotechnology Inc.). Ten micrograms of protein was loaded per lane, and membranes were probed with polyclonal rabbit anti-FOXP3 antiserum (22), followed by goat anti-rabbit-HRP (DakoCytomation). Membranes were stripped and reprobed with anti-p38 (Santa Cruz Biotechnology Inc.) or anti-ERK antibodies (Cell Signaling Technology) to assess loading equivalency.

Retroviral constructs and transduction of $\mathrm{CD} 4^{+} \mathrm{T}$ cells. The Moloney murine leukemia virus-based vector encoding hFOXP3, hFOXP3 2 , or HA-tagged hFOXP3 amino terminus under control of the long terminal repeat, and $\triangle$ NGFR or GFP under control of the SV40 promoter was generated from the LXS $\triangle \mathrm{N}$ (11) or LXSG vector (a kind gift of C. Traversari, Molmed, Milan, Italy). For production of retrovirus, stable AM12 cell lines expressing retroviral vectors were established and cloned on the basis of high viral titer and expression of both transgenes. Viral supernatants were collected and concentrated using Amicon centrifugation filters (Millipore), and titers of $2 \times 10^{9} / \mathrm{ml}$ were routinely confirmed by infection of $3 \mathrm{~T} 3$ cells. $\mathrm{CD}^{+} \mathrm{CD} 25{ }^{-} \mathrm{CD} 45 \mathrm{RA}^{+} \mathrm{T}$ cells were activated for 48 hours with immobilized anti-CD3 mAbs ( $1 \mu \mathrm{g} / \mathrm{ml}$ OKT3; Orthoclone; Ortho Biotech Products), soluble anti-CD28 mAbs ( $1 \mu \mathrm{g} / \mathrm{ml}$; BD Biosciences - Pharmingen), and recombinant human IL-2 (100 U/ml; Chiron) in complete medium (X-VIVO 15 [Cambrex Corp.], supplemented with $5 \%$ pooled human serum [Cambrex Corp.], and penicillin/streptomycin [Invitrogen Corp.]). Alternatively, $\mathrm{T}$ cells were prestimulated for 48 hours with a 1:1 ratio of autologous APCs (CD3-depleted PBMCs, irradiated at $50 \mathrm{~Gy}$ ), soluble anti-CD3 $(1 \mu \mathrm{g} / \mathrm{ml})$, and IL-2. Two successive rounds of infection were performed on retronectin-coated plates using 20 virus particles per cell and $8 \mu \mathrm{g} / \mathrm{ml}$ Polybrene (Sigma-Aldrich) (11). $\triangle \mathrm{NGFR}^{+}$-transduced T cells (routinely $20-40 \%$ ) were purified with anti-NGFR magnetic beads following the manufacturer's instructions (Miltenyi Biotec).

For double-transduction experiments, an MOI of 10 for each virus was used for simultaneous infection of activated CD $4^{+} \mathrm{CD} 25^{-} \mathrm{CD} 45 \mathrm{RA}^{+} \mathrm{T}$ cells. The efficiency of double transduction was approximately $5 \%$, and the $\Delta \mathrm{NGFR}^{+} / \mathrm{GFP}^{+} \mathrm{T}$ cells were sorted on a BD FACS Aria 6 days following transduction. Cells sorted by magnetic beads (Miltenyi Biotec) or FACS were either used for biological experiments 10-14 days after activation or restimulated and expanded under conditions that preserve Treg cell activity $(4,11)$. Untransduced $T$ cells were tested in parallel to ensure the transduction and purification process itself did not alter the phenotype or function (data not shown). Results from untransduced or transduced $\mathrm{T}$ cells tested upon entry into the resting phase immediately after transduction or following reactivation and expansion were identical.

Transient transfection reporter assays. Jurkat cells were cotransfected using Lipofectamine 2000 (Invitrogen Corp.) with an hIL-2 promoter $(-305$ to +39$)$ luciferase reporter plasmid (a kind gift of Dan Mueller, Department of Medicine and Center for Immunology, University of Minnesota Medical School) and control- (LX-), FOXP3-, or FOXP3 2 encoding plasmids. A plasmid encoding $\beta$-galactosidase under control of an elongation factor- $1 \alpha$ promoter was also included to normalize for transfection efficiency. After overnight culture, cells were left unstimulated or stimulated with PMA $(50 \mathrm{ng} / \mathrm{ml})$ and $\mathrm{Ca}^{2+}$ ionophore $(1 \mu \mathrm{g} / \mathrm{ml})$ for 6 hours. Cells were harvested and lysates prepared in $\times 1$ reporter lysis buffer (Promega). Luciferase activity was measured using the luciferase assay system (Promega) and the EG\&G Berthold Lumat luminometer. The $\beta$-galactosidase activity of each sample was determined using the $\beta$-Galactosidase Enzyme Assay System (Promega) and was used to normalize the measured luciferase activity.

Flow cytometric analysis. Analysis of CD25 (Miltenyi Biotec), HLA-DR, CD122, CTLA4, CCR4 (BD Biosciences - Pharmingen), GITR (R\&D Systems), and CD45RO (CALTAG Laboratories) expression was performed on resting (at least 12 days after activation) $\mathrm{T}$ cell lines. Intracellular CLTA4 staining was performed as previously described (11). For detection of intranuclear expression of HA-FOXP3, cells were stained with biotinylated anti-NGFR mAbs (ATCC), fixed with $2 \%$ formaldehyde at $-20^{\circ} \mathrm{C}$, permeabilized with $90 \% \mathrm{MeOH}$ on ice for 30 minutes, and subsequently incubated with streptavidin-coupled PC5 (Beckman Coulter) and FITC-coupled anti-HA (3F10; Roche Applied Science). Samples were either read on a BD FACSCanto or FACSCalibur and analyzed with FCS Express Pro Software version 2 (De Novo Software).

Determination of cytokine concentration. To determine amounts of IL-2 and IFN- $\gamma$, capture ELISAs (BD Biosciences - Pharmingen) were performed on supernatants after activation with immobilized anti-CD3 mAbs $(1 \mu \mathrm{g} / \mathrm{ml})$, with or without anti-CD28 mAbs $(1 \mu \mathrm{g} / \mathrm{ml})$, for 24 hours (for IL-2) or 48 hours (for IFN- $\gamma$ ). To determine cytokine concentrations in suppression assays, Th1/Th2 cytometric bead assays (BD Biosciences - Pharmingen) were used to assay culture supernatants after 36 hours (for IL-2) or 72 hours (for IFN- $\gamma$ ).

Proliferation and suppression of $T$ cells. Transduced $\mathrm{T}$ cells were plated at 50,000 cells/well in 96-well plates coated with anti-CD3 mAbs, in the presence or absence of IL-2 $(100 \mathrm{U} / \mathrm{ml})$. Proliferation was assessed after 72 hours, after addition of $\left[{ }^{3} \mathrm{H}\right]$ thymidine $(1 \mu \mathrm{Ci}$ per well; Amersham Biosciences). To test for suppressive capacity, autologous $\mathrm{CD} 4^{+} \mathrm{T}$ cells $(50,000$ cells/well) were stimulated with either soluble anti-CD3 mAbs $(1 \mu \mathrm{g} / \mathrm{ml})$ in the presence of APCs (CD3-depleted PBMCs, irradiated at 50 Gy, 50,000 cells/well). Transduced $\mathrm{T}$ cells were added, and suppression was assessed by determining $\left[{ }^{3} \mathrm{H}\right]$ thymidine incorporation and measuring the amounts of IL- 2 and/or IFN- $\gamma$ present in supernatants. Ex vivo $\mathrm{CD} 4{ }^{+} \mathrm{CD} 25^{+}$Tregs were included as a positive control in all experiments. In some cases, autologous $\mathrm{CD}^{+} \mathrm{T}$ cells were labeled with CFSE $(2.5 \mu \mathrm{M}$; Invitrogen Corp. $)$ and cultured in the absence or presence of the transduced $\mathrm{T}$ cells at a 1:1 ratio or freshly isolated $\mathrm{CD}^{+} \mathrm{CD} 25^{+}$Tregs. After 96 hours, the amount of CFSE dye dilution was analyzed by gating on $\mathrm{CD}^{+}$, 7 -amino-actinomycin $\mathrm{D}$-negative, and $\triangle$ NGFR $^{-} \mathrm{T}$ cells. 
Statistics. All analysis for statistically significant differences was performed with 1 -tailed paired Student's $t$ test. $P$ values less than 0.05 were considered significant. All cultures were performed in triplicate, and error bars represent the SD.

\section{Acknowledgments}

We gratefully acknowledge the support of Barrett Benny, Michael Barnett, and Raewyn Broady at the Cell Separator Unit, Vancouver General Hospital, for providing PBMCs. This work was supported by grants from the Canadian Institutes for Health Research (MOP57834 and MOP127506, to M.K. Levings), the British Columbia Transplant Society (to M.K. Levings), the Italian Telethon Foundation (to M.G. Roncarolo), and the NIH (AI48779, to S.F. Ziegler). M.K. Levings holds a Canada Research Chair in Transplantation and is a Michael
Smith Foundation for Health Research Scholar. S.E. Allan holds a Michael Smith Foundation for Health Research Junior Graduate Studentship Award.

Received for publication February 8, 2005, and accepted in revised form July 26, 2005.

Address correspondence to: Megan K. Levings, Department of Surgery, 2660 Oak Street, Vancouver, British Columbia V6H 3Z6, Canada. Phone: (604) 875-4497 ext. 66742; Fax: (604) 875-4497; E-mail: mlevings@interchange.ubc.ca.

Paul C. Orban's present address is: Centre for Molecular Medicine and Therapeutics (CMMT), University of British Columbia, Vancouver, British Columbia, Canada.
1. Levings, M.K., Bacchetta, R, Schulz, U., and Roncarolo, M.G. 2002. The role of IL-10 and TGF-beta in the differentiation and effector function of $\mathrm{T}$ regulatory cells. Int. Arch. Allergy Immunol. 129:263-276.

2. Sakaguchi, S. 2004. Naturally arising CD4+ regulatory $\mathrm{T}$ cells for immunologic self-tolerance and negative control of immune responses. Annu. Rev. Immunol. 22:531-562.

3. Shevach, E.M., McHugh, R.S., Piccirillo, C.A., and Thornton, A.M. 2001. Control of T-cell activation by CD4+ CD25+ suppressor T cells. Immunol. Rev 182:58-67.

4. Levings, M.K., Sangregorio, R., and Roncarolo, M.G. 2001. Human CD25+CD4+ T regulatory cells suppress naive and memory $\mathrm{T}$-cell proliferation and can be expanded in vitro without loss of function. J. Exp. Med. 193:1295-1302.

5. Dieckmann, D., Plottner, H., Berchtold, S., Berger, T., and Schuler, S. 2001. Ex vivo isolation and characterization of $\mathrm{CD} 4+\mathrm{CD} 25+\mathrm{T}$ cells with regulatory properties from human blood. J. Exp. Med. 193:1303-1310.

6. Jonuleit, H., et al. 2001. Identification and functional characterization of human CD4+CD25+ $\mathrm{T}$ cells with regulatory properties isolated from peripheral blood. J. Exp. Med. 193:1285-1294.

7. Taams, L.S., et al. 2001. Human anergic/suppressive CD4(+)CD25(+) T cells: a highly differentiated and apoptosis-prone population. Eur. J. Immunol. 31:1122-1131.

8. Ng, W.F., et al. 2001. Human CD4(+)CD25(+) cells: a naturally occurring population of regulatory $\mathrm{T}$ cells. Blood. 98:2736-2744.

9. Godfrey, W.R., et al. 2004. In vitro-expanded human CD4(+)CD25(+) T-regulatory cells can markedly inhibit allogeneic dendritic cell-stimulated MLR cultures. Blood. 104:453-461.

10. Jiang, S., Camara, N., Lombardi, G., and Lechler, R.I. 2003. Induction of allopeptide-specific human CD4+CD25+ regulatory $\mathrm{T}$ cells ex vivo. Blood. 102:2180-2186.

11. Levings, M.K., et al. 2002. Human CD25+CD4+ T suppressor cell clones produce transforming growth factor $\beta$, but not interleukin 10 and are distinct from type 1 T regulatory cells. J. Exp. Med. 196:1335-1346.

12. Baecher-Allan, C., Viglietta, V., and Hafler, D.A. 2004. Human CD4+CD25+ regulatory T cells. Semin. Immunol. 16:89-98.

13. Wildin, R.S., Smyk-Pearson, S., and Filipovich, A.H. 2002. Clinical and molecular features of the immunodysregulation, polyendocrinopathy, enteropathy, X linked (IPEX) syndrome. J. Med. Genet. 39:537-545.

14. Khattri, R., Cox, T., Yasayko, S.A., and Ramsdell, F. 2003. An essential role for Scurfin in CD4+CD25+ T regulatory cells. Nat. Immunol. 4:337-342.

15. Hori, S., Nomura, T., and Sakaguchi, S. 2003. Control of regulatory $\mathrm{T}$ cell development by the transcription factor Foxp3. Science. 299:1057-1061.

16. Fontenot, J.D., Gavin, M.A., and Rudensky, A.Y. 2003. Foxp3 programs the development and function of CD4+CD25+ regulatory T cells. Nat. Immunol. 4:330-336.

17. Walker, M.R., et al. 2003. Induction of FoxP3 and acquisition of $\mathrm{T}$ regulatory activity by stimulated human $\mathrm{CD}^{+} \mathrm{CD} 25^{-} \mathrm{T}$ cells. J. Clin. Invest. 112:1437-1443. doi:10.1172/JCI200319441.

18. Yagi, H., et al. 2004. Crucial role of FOXP3 in the development and function of human CD25+CD4+ regulatory T cells. Int. Immunol. 16:1643-1656.

19. Morgan, M.E., et al. 2005. Expression of FOXP3 mRNA is not confined to CD4(+)CD25(+) T regulatory cells in humans. Hum. Immunol. 66:13-20.

20. Graca, L., Cobbold, S.P., and Waldmann, H. 2002. Identification of regulatory $\mathrm{T}$ cells in tolerated allografts. J. Exp. Med. 195:1641-1646.

21. Manavalan, J.S., et al. 2004. Alloantigen specific $\mathrm{CD} 8+\mathrm{CD} 28-\mathrm{FOXP} 3+\mathrm{T}$ suppressor cells induce ILT3+ ILT4+ tolerogenic endothelial cells, inhibiting alloreactivity. Int. Immunol. 16:1055-1068.

22. Schubert, L.A., Jeffery, E., Zhang, Y., Ramsdell, F, and Ziegler, S.F. 2001. Scurfin (FOXP3) acts as a repressor of transcription and regulates $\mathrm{T}$ cell activation. J. Biol. Chem. 276:37672-37679.

23. Oswald-Richter, K., et al. 2004. HIV infection of naturally occurring and genetically reprogrammed human regulatory T-cells. PLoS Biol. 2:E198.

24. Gavin, M., and Rudensky, A. 2003. Control of immune homeostasis by naturally arising regulatory CD4+ T cells. Curr. Opin. Immunol. 15:690-696.

25. Cobbold, S., et al. 2004. Induction of foxP3+ regulatory $\mathrm{T}$ cells in the periphery of $\mathrm{T}$ cell receptor transgenic mice tolerized to transplants. J. Immunol. 172:6003-6010.

26. Lin, C.Y., Graca, L., Cobbold, S., and Waldmann, H. 2002. Dominant transplantation tolerance impairs CD8+ T cell function but not expansion. Nat. Immunol. 3:1208-1213.

27. Tai, X., Cowan, M., Feigenbaum, L., and Singer, A. 2005. CD28 costimulation of developing thymocytes induces Foxp3 expression and regulatory $\mathrm{T}$ cell differentiation independently of interleukin 2 . Nat. Immunol. 6:152-162.

28. Grundstrom, S., Cederbom, L., Sundstedt, A., Scheipers, P., and Ivars, F. 2003. Superantigeninduced regulatory $\mathrm{T}$ cells display different suppressive functions in the presence or absence of natural $\mathrm{CD} 4+\mathrm{CD} 25+$ regulatory $\mathrm{T}$ cells in vivo. Immunol. 170:5008-5017.

29. Feunou, P., et al. 2003. CD4+CD25+ and CD4+CD25- $T$ cells act respectively as inducer and effector $T$ suppressor cells in superantigen-induced tolerance. J. Immunol. 171:3475-3484.

30. Roncador, G., et al. 2005. Analysis of FOXP3 protein expression in human $\mathrm{CD} 4+\mathrm{CD} 25+$ regulatory $\mathrm{T}$ cells at the single-cell level. Eur. J. Immunol. 35:1681-1691.

31. Kriegel, M.A., et al. 2004. Defective suppressor function of human CD4+ CD25+ regulatory T cells in autoimmune polyglandular syndrome type II. J. Exp. Med. 199:1285-1291.

32. Sereti, I., et al. 2005. In vivo expansion of CD4+CD45RO-CD25+ T cell expressing foxP3 in IL-2-treated HIV-infected patients. J. Clin. Invest. 115:1839-1847. doi:10.1172/JCI24307.

33. Fontenot, J.D., and Rudensky, A.Y. 2005. A well adapted regulatory contrivance: regulatory $\mathrm{T}$ cell development and the forkhead family transcription factor Foxp3. Nat. Immunol. 6:331-337. 